\title{
Игонин А.И.
}

\section{ПРОБАЕМАТИКА МИГРАЦИИ В ПОАИТОАОГИЧЕСКОМ АНААИЗЕ}

\begin{abstract}
Аннотация. В статье рассматриваются особенности понятия «миграция» в политологическом контексте, где автор предлагает рассмотреть основные подходы к понятию «миграция» и «миграционный процесс» в научной митературе с иелью последующей конкретизации их собственно политологического контекста. Объектом исследования является миграция в научном контексте. Также анализ темы предполагает сравнительное рассмотрение понятий «миграционная политика» $и$ «гсударственная миграционная политика», где автором определяется их разичное толкование, что собственно характкризует предметную область исследования. Актуальность исследования обусловлена тем, что миграчия представляет собой явление глобальных маситабов, разворачивающейся в начале XXI столетия под влиянием множества разнородных факторов. Эти явления, связанные с миграцией, образуют сложный с содержательной точки зрения проблемный комплекс, требующий своего осмысления. Теоретико-методологические основы исследования включают концептуальные положения, содержащиеся в научных трудах отечественных и зарубежных ученьх, специализирующихся в рассматриваемой тематической области, как с точки зрения междисциплинарного знания, так и исследовательского инструментария политической науки, в особенности системный, институциональный, коммуникативный, этнополитический подходы. Научная новизна заключается в том, что систематизированы основные концептуальные подходы к сфере миграции и политико-управленческого воздействия на миграционные прочессы; сформулировано уточняющее авторское понимание соотночения понятий «миграция», миграционнал политика», «государственнал миграционная политика». В итоге можно указать следующее: данный комплекс порождает задачи демографического и антропологчческого, экономического и правоведческого, сочиологического и психологчческого, культурологчческого, этнологического, религиоведческого свойства. В этом тематическом круге свое важное место занимает политологический ракурс познания, так какмиграция, в силу своей массовости и трансграничной природы, не может не иметь значимости с точки зрения политической жизни общества. Отношения миграционных процессов и политики очень тесно взаимосвязаны. Аюбал миграция требует политического реагирования и рассматривается как объект властно-управленческого воздействия. Миграционная проблематика, влиял на общее положение в принимающих странах, затрагивая интересы жителей в этих странах, порождает многообразные притязания со стороны автохтонного населения и диаспор, оказывает многостороннее воздействие на политический процесс и на среду политической системы в иелом.
\end{abstract}

Ключевые слова: миграция, миграционный процесс, миграционная политика, государственная миграционнал политика, политология, адаптация, мультикультурализм, аллокация, эндомиграция, экзомиграция.

Review. The article considers the peculiarities of the notion of migration in the politogical context, where the author suggests to consider the major approaches to the notions of migration and migration process in academic literature, in order to specify their politilogical context. The object of the research is migration in the scientific context. The analysis of the topic implies comparative consideration of the notions «migration politics $\gg$ and «state migration policy $\gg$, which are interpreted differently by the author, which characterises the subjective area of the research. The relevance of the study is based on the fact that migration is a global phenomenon that takes place in the XXI century and is influenced by many heterogenous factors. Such phenomena, connected with migration, comprise a content-wise complicated complex of issues that is to be conceived. Theoretical and methodological bases of the study include concepts contained in the academic works of Russian and foreign researchers specialising in the considered area, both from the point of view of interdisciplinary knowledge and that of the research tools of political science, especially systems, institutional, communicative, ethnic-political approaches. The scientific novelty lies in the fact that the article systematises main conceptual approaches to the field of migration and political-governmental impact on migration processes. The article formulates the author's clarifying understanding of the correlation of the notions «migration», «migration politics», «state migration policy». To sum up, it can be stated that this complex generates demographic, anthropological, economic, legal, sociological, psychological, cultural, ethnological, religious tasks. In this area politological knowledge is of high importance, as migration, due to its mass and trans-border nature, cannot have no significance from the point of view of the political life of the society. The relations 
between migration processes and politics are closely related. Any migration demands political reaction and is considered as an object of power and government. The problem of migration, influencing the general situation in host countries and affecting the interests of the citizens of these countries, creates multiple claims of the autochtonous population and expat communities and impacts the political process and the political environment in general.

Keywords: allocation, multiculturalism, adaptation, political science, state migration policy, migration politics, migration process, migration, endomigration, exomigration.

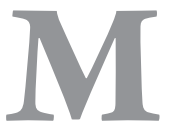

играция - явмение гмобамьного масштаба, под влиянием множества разнородных факторов с новой силой нахлынувшая в начале XXI столетия. Переселение народа всегда обусловлено социальными и экономическими обстоятельствами, ситуацией на рынке труаа и занятости, внутриполитической обстановкой, решающую же роль оказывают гуманитарные катастрофы, мотивации этнополитического и межрелигиозного характера. Но миграция - это не только процесс опреАеленной территориальной мобильности, это состояние примирения с новой среАой, «разрыв опреАеленных групп АюАей со «своими» экологическими, социокультурными, производственными структурами иАентичности и вхожАение в «чужие» структуры идентичности на новой территории» ${ }^{[1]}$. Поэтому явление миграции невозможно рассматривать в рамках одной социогуманитарной науки политологии. Аналогичной точки зрения придерживается Н.И. Шекихачева, утвержАающая, что «миграция по своей этимологии является межАисциплинарной категорией, объектом изучения многих социальных наук, которые типологизируют ее исхоАя из собственных метоАОлогических оснований ${ }^{[2]}$.

В изучении явления миграции в отечественной науке можно выАелить сразу несколько поАхоАов. Первый поАхоА - Аемографический, в рамках которого Аелается акцент на анализ численности и на половозрастную структуру перемещений населения, а также оценивается вмияние миграционных процессов на Аинамику населения тех или иных регионов и госуаарств. Аемографов интересует значение миграции Аля восполнения численности населения страны при изучении естественной и территориальной мобимьности. При этом большинством исследователей не принимают за миграцию те пространственные перемещения, которые совершаются в пределах одного и того же населенного пункта. ОАнако, например, Ю. Н. Козырев относит к миграции все перемещения, которые совершаются внутри населенных пунктов, Ааже если они связаны с посещением торговых преАприятий ${ }^{[3]}$. $\Lambda . \Lambda$. Рыбаковский и Т.И. Заславская разграничивают понятия «мобимьность» и «миграция», понимая поА последним «фактическое перемещение населения».
Миграцию как составмяющую Аемографической науки рассматривают М.Б. Аенисенко, В. А Ионцев и Б. С. Хореев, впервые вводящие название нового направления - «миграциология» ${ }^{[4]}$. В то же время существует мнение о том, что миграция не есть только мишь составная часть Аемографической науки ${ }^{[5]}$. Т. Н. ЮАина подвергает критике целесообразность введения термина «миграциология», так как он описывает только миграционную ПоАвижность населения, но не ПоАвоАит к анализу влияния миграции на целостную жизнедеятельность общества и тех социальных отношений, которые формируются поА ее возАействием ${ }^{[6]}$.

Аругой подход к изучению миграции - экономический - направлен на изучение роли миграции в воспроизводстве человеческих ресурсов Аля экономического развития и в созАании конкуренции на рынке труаа. Социологи Н.Н. Аилух ${ }^{[7]}$, Ж.А. Зайончковская ${ }^{[8]}$, О. $\Lambda$. Рыбаковский ${ }^{[9]}$ считают миграционную политику частью социальноэкономической политики. Так, Н.Н. Аидух утвержАает, что миграционная политика существенно влияет на экономическую структуру и Аолжна способствовать Аостижению важнейших общественных цемей, таких как развитие рыночных отношений, построение Аемократического общества, соблюдение прав человека, интеграция в межАународный рынок труаа.

ЮриАический ПоАхоА в центр внимания ставит проблему правового статуса разцичных категорий мигрантов, а, следовательно, фокусируется на разработке нормативной основы регулирования миграции. Так, оАин из сторонников юридического подхода А.Н. Жеребцов поА миграцией понимает «сознательную, цеменаправленную, подлежащую правовому регулированию Аеятельность субъектов в рамках общественных отношений, возникающих в процессе территориального перемещения мюдей, в результате которой приобретается, прекращается, изменяется и реализуется правовой статус мигранта ${ }^{[10]}$.

Не менее активно развивается и психологический поАхоА, преАставители которого ставят переА собой задачу - понять мотивы переселенцев, то есть непосреАственные побуаительные симы миграции. В частности, С. К. Бондырева 
преАлагает определение миграции как полимотивированного общественного явцения, возможного благодаря мобимьности человека, связанного с его потребностями и реализующегося как в физическом, так и в виртуальном пространстве ${ }^{[11]}$. В то же время в своей работе она также прибегает к терминологии демографов: миграция - это пространственная активность (перемещение) индивида, направленная на овладение ресурсами новых территорий и связанная с переменой места житемьства ${ }^{[12]}$.

Миграция как часть общественного Авижения трактуется основателями социологического подхода. В рамках Аанного подхода к пониманию миграции акцент ставится на поиск способов социальной аАаптации мигрантов, взаимоотношения мичности мигранта и принимающего общества, изучение состава мигрантов, а также вмияния территориальной мобильности населения на социальную структуру общества. К примеру, Т.Н. ЮАина Аает следующее опредемение: «Миграция как изменение социальной структуры и статусных характеристик различных слоев и групп населения государства или региона поА влиянием социальных перемещений населения или его части за преАелы государственной или аАминистративной границы на относительно Алитемьный срок» ${ }^{[13]}$.

Подобное многообразие определений миграции присутствует не только в отечественной науке, зарубежные ученые также не пришли к еАиному толкованию понятия. Хотелось бы отметить оАно из наиболее удачных, на наш взгляА, определений, Аанное швейцарским исследователем Р. ПерручоуАом. Подчеркивая отсутствие согласованного понимания термина «миграция», он обращает внимание на субъектный состав миграции: беженцы, перемещенные мица и экономические мигранты. Р. Перручоуд в своем определении миграции говорит не только о самом факте перемещения населения, но и уточняет, что переселение может быть как временным, так и постоянным ${ }^{[14]}$.

Многообразие подходов (Аемографический, экономический, юридический, психологический, социологический) объясняется тем, что разные авторы - представитеки определенных социогуманитарных наук - берут за основу те или иные обоснования, близкие «своей» отрасли знания, что в сумме Аает наиболее полное представление о понятии миграции. МежАисципиинарность исследования понятия миграции (которая отмечацась А. А. Акмамовой и В. М. Капицыным) в Аанном контексте явцяется принципиальной, поскольку политологический аспект Аолжен Аополняться Аемографическим, экономическим, юриАическим, социологическим и психологическим компонентами.

В традиционных работах по политологии проблема миграции рассматривается в основном с точки зрения влияния территориальной мобильности населения на политические процессы, происходящие в госуаарстве, на их значение Аля функционирования государственно-политических институтов. СреАи ученых-политологов, занимающихся проблемами миграции населения, можно назвать А. Я. Анцупову, А. В. Баранова, С. Н. Бобылеву, О. А. Воробьева, В. Г. Гельбраса, А. И. Аемидова, А. В. Арагунского, В. С. Мацахова, В. И. МукомеАя, И. В. Аукьянову, Г. С. Працко, С. А. Прошанова, Е. В. Сальникова, С. А. Трыканова, А. Р. Файзумлину, А. Е. Шапарова, А. П. Шмемева, Ю. Г. Ефимова и некоторых Аругих ${ }^{[15]}$.

Надо отметить, что наибольший всплеск изучения проблем миграции в науке происходим в начаме 1990-х годов: скмадываются научные комлективы, изучающие размичные аспекты миграционной ситуации в России, в том числе и Центр этнополитических и региональных исслеАований поА РуковоАством В. Мукомеля и Э. Паина. Подобный интерес был вызван внутриполитическими событиями: распаА СССР, вслеАствие которого происходили массовые перемещения населения, поднимались вопросы социокультурного, политического и социально-экономического поряАка.

В научной политологической митературе закрепилось несколько определений миграции. Нам бы хотелось привести примеры наиболее точных и информативных определений и проанализировать их. «Миграция - перемещение мюдей, этносов, их частей, отАельных преАставителей, связанное со сменой постоянного места проживания или с возвращением в него. Миграция населения - сложный по своей природе, многообразный по формам и послеАствиям социальный процесс. Оказывая огромное влияние на общественное развитие, он сам Подпадает поА возАействие Политических, социально-экономических, Аемографических и иных трансформаций ${ }^{[16]}$.

Широкое понимание Аанного термина принаАмежит О.А. Воробьевой: это мюбое территориацьное перемещение населения, связанное с пересечением как внешних, так и внутренних границ аАминистративно-территориацьных образований с цемью смены постоянного места жительства или временного пребывания на территории Аля осуществцения учебы или трудовой Аеятельности независимо от того, поА возАействием каких факторов оно происходит. Наряду с этим некоторые исследователи 
выдемяют «внутреннюю миграцию» и «внешнюю миграцию». Если «внутренняя» включает в себя перемещения в преАелах оАной страны межАу аАминистративными районами, насеменными пунктами, то «внешняя миграция» всегда связана с пересечением государственных границ. Исследователь Т. Н. ЮАИна преАложила ввести подклассификацию «внешней миграции», выдемяя эмиграцию, иммиграцию и реэмиграцию (репатриацию), то есть Аобровольное, самостоятельное возвращение эмигрантов на роАину ${ }^{[17,18]}$.

Особый интерес преАставмяет определение миграции, Аанное Ю.Г. Ефимовым: «Миграция в политологическом понимании - это изменения политической реальности госуАарства или региона поА влиянием социальных перемещений населения или его части за преАелы государства или аАминистративной границы на относительно Алитемьный срок» ${ }^{[19]}$. Ефимов выделяет устойчивое интеграционное «яАро» и «периферию» политических интересов мигрантов и местного населения. Он отмечает, что «Аля кажАого исторического периода характерны свои, специфические «яАро» и «периферия $\gg$ интеграции, что влияет на степень социальной и политической напряженности в обществе» ${ }^{[20]}$.

В этом же ряду стоит позиция А. Е. САизовского: «С политологической точки зрения, все виАы миграции и миграционной политики, хотя и в разной степени, могут рассматриваться как политические Аействия. Миграцию, только как политическое Аействие, во-первых, Аолжно (можно) мыслить при всех обстоятельствах не как нечто самостоятельное, а как орудие политики; только при таком понимании становится возможным не впасть в противоречие со всей историей миграции. Во-вторых, именно такая точка зрения показывает нам, как размичны, Аолжны быть виды и типы миграции в зависимости от мотивов и обстоятельств, из которых они зароЖАаются» ${ }^{[21]}$.

Подытоживая анализ Аанных опредемений, можно сказать, что миграция рассматривается исследователями как социальный процесс перемещения насемения, который непосреАственно влияет на политическую жизнь государства.

Чуть выше мы уже говорили о возможных классификациях видов миграции. Хотелось бы отметить наиболее полную и всеобъемлющую киассификацию, которую разработал С.Н. Градировский ${ }^{[22]}$. Первым уровнем кмассификации миграций этот специалист опредемяет наличие и характер цели как кАючевого параметра Аюбого Авижения, а также параметры пространства-времени, качественные и комичественные измерения. ЗАесь наиболее важным
преАставцяется разделение миграций относительно границ (аАминистративных, историко-культурных, социокультурных и географических). По указанному критерию все миграции можно классифицировать на «внутренние» (эндомиграции) - перемещения в пределах оАной страны межАу аАминистративными районами, населенными пунктами и «внешние» (экзомиграции), при которых пересекаются государственные границы. Экзомиграции Аелятся на эмиграционные и иммиграционные (относительно страны-донора - «отАающего» общества и реципиента — «принимающего» общества).

Основываясь на приведенных определениях и классификациях отечественных и зарубежных исслеАователей, мы преАлагаем рассматривать миграцию как фактор, оказывающий существенное возАействие (при достижении определенных социально-демографических и экономических масштабов и параметров, а также этно-культурных измерений) на политический процесс в условиях «принимающей стороны». При этом поА политическим процессом мы понимаем послеАовательную и продолжительную по времени смену состояний политической системы, ее поАсистем мибо изменение в них отАельных элементов, которые совершаются поА влиянием внутренних и внешних условий жизни общества. Политический процесс характеризуется, как правило, конкретным порядком взаимодействия его компонентов и разными темпами на кажАой из своих стаАий. Поскольку, с оАной стороны, он опреАемяет Аинамику политической жизни как «принимающего», так и «отАающего» общества, то есть происходит политизация миграционного процесса. Политика явцяется сферой, в которой принимаемые решения возАействуют на все поАсистемы общества и процессы в нем (в том числе и миграционные), что привоАит к появлению политического компонента в миграционном процессе.

Наряду с этим деятельность участников (субъектов) миграционных процессов (миграцию относят к классу спонтанных социальных процессов, возникающих поА воздействием разАичных факторов и осуществмяющихся как общественная инициатива) связана с тем, чтобы их интересы были учтены в рамках существующей политической системы общества и в ходе принятия соответствующих решений.

Таким образом, миграционный процесс явмяется частью политического процесса, возникающего вслеАствие территориального перемещения мюАей, имеет Авойственный характер, который определяет Аинамику развития во всех сферах как «принимающего», так и «отАающего» общества; Аеятельность 
субъектов миграционного процесса (мигрантов) имеет массовый характер, их интересы должны быть решены посреАством мер политического характера.

Учет теоретических оснований понятия «миграционная политика» позволяет выделить некоторые варианты его соотношения с понятием «госуАарственная миграционная политика». (Многие авторы фактически ставят знак равенства между понятийными конструкциями, о которых идет речь).

«Миграционная политика есть система усмовий, способов и мер управления миграционной подвижностью населения $\gg,-$ считает Б. С. Хорев. Аналогичной точки зрения придерживается А. У. Хомра: «Миграционная политика - это комплекс разработок и мероприятий, направменных на формирование необходимых потоков и требуемой миграции насемения» ${ }^{23]}$. Согласно позиции $\Lambda$. Мармора, миграционная политика - это политика государственная, и направлена она на изменение численности, состава, направления Авижения, местонахожАения и интеграции мигрантов, которые явмяются элементом политики народонаселения и тесно связаны с Аемографической проблематикой, так как вмияют как на численность и состав, так и на распредемение населения, и, кроме того, неизбежно включаются в Аанный исторический процесс ${ }^{\text {[24]. }}$

Политологический аспект при анализе миграционной политики сосредоточен на регумировании миграции посреАством политических институтов, прежде всего государства. НаАо отметить, что еще основоположник отечественной миграциологии $\Lambda . \Lambda$. Рыбаковский рассматриваемый преАмет преАставля как «систему общепринятых на уровне управления идей и концептуацьно объединенных среАств, с помощью которых, прежАе всего госуАарство, а также его общественные институты, соблюдая определенные принципы, соответствующие конкретно-историческим условиям страны, предполагает достижение целей, адекватных как этому, так и последующему этапу развития общества ${ }^{[25]}$.

Взаимодействие миграционных процессов и политики - многостороннее явление, которое требует политического реагирования, объект властно-управленческого возАействия со стороны властных инстанций и всей совокупности политических акторов. Отсюда вытекает настоятельная потребность в разработке эффективной и адекватной меняющейся среде миграционной политики.

Как считает В.А. Ионцев, миграционная политика «есть система политических мер, постановлений, законодатемьных актов и соглашений (сначала Авусторонних, а затем и многосторонних) межАу... государствами по регулированию миграционных потоков ... » ${ }^{[26]}$.

По мнению А. Е. Шапарова, миграционная помитика преАставляет собой комплекс мероприятий, относящихся к сфере государственного управления, вкАючая процесс принятия решений, который проявмяется через амлокацию ценностей, регулируемую правовыми нормами, контролируемую преАставительной властью, и направленных на упорядочение миграционных процессов ${ }^{[27]}$.

В.И. Мукомель в своей работе указывает, что миграционная политика, как и мюбая иная, зижАется на четырех столпах: законодательстве, организационном (институционамьном) ее сопровождении, инструментах реализации и финансировании ${ }^{[28]}$.

Зарубежные политологи (мы опираемся на работы А. Золберга, Г. Фримана, Аж. ХомиифимАа, С. Штеттера ${ }^{[29]}$ ) целью государственной Аеятельности в миграционной сфере считают определение стратегии контромя за въезАом и выезАом инАивиАов, установление критериев принаАлежности к обществу путем процеАур натурахизации и обретения гражАанства, рассматривают влияние политических систем и институтов на регумирование иммиграции.

Итак, перечисленные выше подходы к миграционной политике делают акцент на государственное начало. В связи с этим, на наш взгляА, разумно рассматривать миграционную политику, выделяя в ней государственное яАро, то есть собственно государственную миграционную политику. ПодтвержАение этому мы находим в определении, Аанном В. М. Бобылевой: «Миграционная политика - это система принципов, цемей и Аействий, с помощью которых государство и иные политические акторы регулируют потоки пересеменцев» ${ }^{[30]}$. Государственная политика преАставмяет собой целенаправленное решение заАач в социальной, экономической, оборонной и Аругих сферах общественной жизни, выражающее Аоминирующие приоритеты и ценности применения вАасти ${ }^{[31]}$.

Миграционная политика - сложно организованное явление, которое складывается из помитических отношений с участием разнородных акторов: правящих и неправящих сил, институтов вмасти и влияния, заинтересованных групп, ассоциаций работодателей и наемных работников, помитических партий и организаций, этнокультурных и этнорелигиозных сообществ. В таком понимании термин «миграционная политика» тяготеет к обмасти politics, то есть всему пространству политически значимых отношений, интересов, видов Аеятельности, практик, преАпринимаемых со стороны всего спектра субъектов. В Аанном контексте policy 
понимается как программа Аействий, то есть соотносится с объективной стороной. «Policy, - пишет Р. Арон, - концепция, программа Аействий, а то и само Аействие оАного человека, группы мюАей, правительства» ${ }^{[32]}$. Государственная миграционная политика в Аанном исследовании понимается как целенаправленное воздействие институтов власти на распределение и перераспределение миграционных потоков с целью создания благоприятных условий Аля принимающих стран и минимизации Аестабилизирующих рисков миграции. В этом отношении государственная миграционная политика по смысловому наполнению ближе к категории policy, то есть к практике разработки и реализации политического курса, связанного со стратегическим цемеполаганием.

Различие межау policy и politics П. Рикер понимает как различие межАу «политикой» и чисто «политическим». Согласно П. Рикеру, «политическое» обретает смысл в результате рефлексии, то есть ретроспективно. Смысл «политики» раскрывается в проецировании «будущего», необходимость которого П. Рикер соотносит с кризисными моментами как «переломными» этапами истории. «Политическое - это разумная организация, — пишет П. Рикер, - помитика - это решение: анализ возможных ситуаций, пари возможного будущего. Не существует политического без политики» ${ }^{[33]}$.

Существующее различие между policy и politics позволяет преАставить политику как программу Аействий в качестве «политической Аействительности». Смысл «Аействительности» политики раскрывается в принятии решений, то есть по своей сути явмяется его преАсказанием «буАущего». В Аанном случае «Аействительность» политики связана со сферой возможного как «еще-неосуществившейся» реальностью «будущего». Политику как систему знания можно рассматривать в качестве «политической реацьности», которая явцяется результатом научной рефмексии.

Политологическая значимость миграционной проблематики связана с обеими названными смысловыми гранями. ПоА возАействие того и Аругого формируется «иммиграционный режим» (В. С. Мамахов). Это совокупность институциональных оснований, определяющих как условия въезда (иммиграционная политика), так и политические условия инкорпорирования в общество прибывающих групп (интеграционная политика).

Наконец, миграционная проблематика, влияя на общее положение в принимающих странах, затрагивая интересы большого числа групп в этих странах, порожАая многообразные притязания со сто- роны автохтонного населения и Аиаспор, оказывает многостороннее возАействие на политический процесс и на среду политической системы в целом. Во всех своих компонентах взаимодействие миграционных и политических процессов, а также на макро-, мезо- и микросоциальном уровнях, становится преАметом использования в политических технологиях многих партийно-политических сил. Тем самым миграционные проблемы, подвергаясь политизации, оказываются в ситуации прямой и обратной связи с электорацьными процессами.

Все сказанное включает в себя значимые политико-Аискурсивные компоненты, которые связаны с различными формами и уровнями артикумяции позиций и интересов, прямо или косвенно обусловменных миграционными ситуациями, а также с размичными сценариями проектирования желатемьных иммиграционных режимов.

Отличительной чертой госуАарства является обладание монополией на организованное насилие как ресурс власти, с оАной стороны, а с Аругой оно явмяется гарантом безопасности гражАан, проживающих на его территории. Государство облаАает монополией на изАание законов и норм, обязательных Аля всего населения, а значит, в состоянии координировать и контролировать миграционные процессы. В государственной миграционной политике находит отражение целенаправленное решение задач в сфере регулирования миграционных процессов, выражающее Аоминирующие приоритеты и ценности применения государственной власти.

Исходя из этого, можно утвержАать, что госуАарственная миграционная политика Аолжна обязательно содержать в себе Аве структурные части: стратегию и тактику. А содержание технологий и процеАур планирования конкретизируется в зависимости от его стратегического ики тактического характера государственной помитики.

Следовательно, в концепции миграционной политики Аолжен присутствовать стратегический уровень - ее цели. Необходим также учет заАач тактического уровня. Причем тактикой являются четко фиксированные в своей последовательности способы поведения, ориентированные на достижение конкретных целей, явмяющихся звеньями реамизации стратегических цемей ${ }^{[34]}$.

Политическая тактика занимает подчиненное положение по отношению к политической стратегии. Политическая стратегия в государственной миграционной политике преАставляет собой основную целеполагающую «канву» решений, направленную на Аостижение Аолгосрочных целей. В то время как тактическая Аеятельность Аолжна преАставлять 
собой меры, направменные на достижение промежуточных результатов такой Аеятельности. При рассмотрении Аанного феномена целесообразно исходить из основополагающих целей государства, а именно подАержание национахьной безопасности (подАержание функционирования его базового помитического процесса). Следовательно, регулирование миграционных процессов - это одна из стратегических целей государства.

Структурно-функционацьные концепции явмяются принципиацьными Аля нашего исследования, так как они рассматривают политику как целостный, сложный механизм, находящийся в непрерывном взаимодействии с окружающей среАой через «вхоА» и «выхоА» системы. Согласно концепции Т. Парсонса и А. Истона, политическая система как «открытая», иерархичная, саморегулирующаяся, Аинамическая испытывает на себе влияние окружающей среАы (то есть миграционного процесса, Аетерминированного размичными требованиями). С помощью механизмов саморегумяции она вырабатывает ответные реакции, аАаптируясь к внешним условиям, то есть принимает адекватные требованиям «входа» миграционного процесса «политические решения» в виде формирования стратегии государственной миграционной политики. Этот контроль может варьироваться от способности предотвратить или «пресечь» какие-то нарушения Ао способности бцагоприятным Аля себя образом формировать отношения со средой»,- - отмечал Т. Парсонс ${ }^{[35]}$.

А. Истон выделия аве среды (окружения) помитической системы: интрасоциетацьные - экономическая, социальная, кумьтурная - подсистемы общества; экстрасоциетальные - Аругие общества, межаународные институты и отношения ${ }^{[36]}$. Это имеет принципиальное значение с точки зрения выделения интрасоциетальных (внутренних) и экстрасоциетальных (внешних) факторов в государственной миграционной политике.

Интрасоциетальные (внутренние) факторы созАают почву Аля опреАеления условий формирования миграционных потоков, связанных с политической системой общества. Они, в свою очереАь, определяются текущей миграционной ситуацей. Так, государственная миграционная политика Аолжна учитывать проблемы экономического развития страны. Социальные факторы диктуются прежАе всего текущей Аемографической ситуацией, а уже затем - переАвижением социацьных групп (например «утечкой умов»). Кумьтурная подсистема обеспечивает преемственность социокультурных ценностей народа, следовательно, связана с воссоединением /
присоеАинением к культуре «принимающего» общества, поэтому рассмотрение Аихотомии «мультикумьтурализм» - «локализм» будет иметь значение Аля нас при последующем продолжении анализа.

Внешние факторы в государственной миграционной политике - это, в первую очереАь, моменты, связанные с «глобализацией». Ее всеобъемлющее значение определяется развитием наАнациональных отношений межАу экономическими, социальными и иными субъектами размичных стран, которые становятся более значимыми по сравнению с внутрисоциальными условиями. Происходит эволюция объектов и субъектов мирохозяйственного общения, повышается пространственная мобильность интемлектуально-информационного труда (рабочей силы) [37]. Аалее - международные обязательства, межправительственные соглашения и другие нормативные факторы в области миграции. Как справеАливо указывает А.Е. Шапаров, совместная Аеятельность государств по регулированию различных аспектов межАународной миграции преАполагает сближение принципов национацьных иммиграционных политик, а также выработку общих Аля участников интеграционных процессов норм, правил и процеАур в форме регионацьных и межАународных миграционных режимов ${ }^{[38]}$. Наряду с этим необходимо учитывать и «реэмиграционный» фактор, которому подчас не придается особого значения.

Приведенное разграничение, разумеется, весьма условно. Следует согласиться с мнением С. Е. Метелева: «Выработка отклика страны на вызовы времени в современном мире во многом зависит от возможностей и характеристики ее участия в формировании потоков международных мигрантов. Разные Аинамические и структурные параметры потоков межаународных мигрантов будут по разному возАействовать на изменения отАельных сторон национального хозяйства, и эти возАействия по своему характеру могут быть значимыми и незначимыми, мокальными, региональными и макроэкономическими, позитивными, нейтрацьными и негативными. Они способны по-разному вциять на технико-экономическую структуру, отраслевое развитие страны, межкультурное взаимодействие и этнокультурные изменения, на систему власти и Аоступа коренного и иностранного населения к национальным ресурсам, формальные и неформальные институты, рынки труАа и капиталов, структуру занятости населения и безработицу, Аоходы и расходы государственного и муниципального бюАжетов, краткосрочные, среАнесрочные и Аолгосрочные процессы и т.А. ${ }^{[39]}$.

Исходя из этого, Политическая система Аолжна аАекватно выражать текущие «требования среды 
на входе» в области миграции и решать их в виде принятия политических решений, «выхоА» формулированием аАекватной государственной миграционной политики. Она Аолжна базироваться на основополагающей цеми государства - поААержании общественной стабильности и исходить из реального состояния миграционных процессов. Реагируя на импульсы, идущие из внешней среды, система сохраняет способность к устойчивому функционированию и развитию, то есть избегает конфликтов, вызванных миграционной среАой.

На основании вышеизложенного, стратегия государственной миграционной политики Аолжна быть аАекватна текущим требованиям внешних и внутренних факторов, гАе основополагающим явцяется поААержание жизнеспособности системы в целом.

Госуаарство опреАемяет Аинамику базового (общенационального) ими мегауровня политического процесса посреАством издания формальнонормативных актов с последующей их реализацией через миграционные органы и с соответствующим контролем. Политические процессы начинают Аетерминироваться миграционными потоками, миграция становится неотъемлемым элементом системы национацьной безопасности государства. Это приводит к тому, что наблюАается политизация миграционных процессов. На этом уровне формируются стратегические концепции регулирования миграционных процессов.

На региональном или мезоуровне политического процесса происходит трансляция с вышестоящего уровня: стратегические цели подАержания целостности государства путем контролирования миграционных потоков, аАаптация на основании текущей ситуации в регионе.

Как мы уже упоминами, миграционные процессы Авумерны не только по своему строению, но и по природе своего происхожАения и протекания: «эмиграция» и «иммиграция». Исходя из этого, В.В. Аюбецкий ${ }^{[40]}$, И. В. Аукьянова ${ }^{[41]}$ разАеляют миграционную политику на эмиграционную и иммиграционную.

Мы придерживаемся точки зрения В.А. Суворовой, которая рассматривает иммиграционную по-

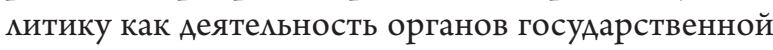
власти, выражающую государственные интересы (социальные, Аемографические, экономические, политические) при приеме на территории страны иностранцев и миц без гражданства, намеревающихся остаться в стране на постоянное или временное место жительства ${ }^{[42]}$.

Эмиграционная политика государства состоит из нескольких направлений: ограничение трудо- вой миграции, созАание условий Аля реэмиграции и аАаптации реэмигрантов на родине ${ }^{[43]}$. Основная цемь эмиграционной политики заключается в эмиграции трудовых ресурсов, которая Аолжна способствовать сокращению безработицы, поступлению от труАящихся-эмигрантов валютных среАств, которые используются Аля сбалансированности экспортно-импортных операций.

Явмения, связанные с миграцией, образуют сложный с содержательной точки зрения проблемный комплекс, требующий осмысления со стороны разных специалистов: экономистов, политологов, социологов, психологов, юристов и Ар. При этом особое место занимает именно политологический ракурс познания, так как миграция, в сику своей массовости и трансграничной природы, не может не иметь значимости с точки зрения политической жизни общества.

Отношения миграционных процессов и помитики очень тесно взаимосвязаны. Аюбая миграция требует политического реагирования и рассматривается как объект властно-управценческого возАействия. В результате актуализируется необходимость в разработке эффективной и Аинамично отвечающей меняющейся среАе миграционной политики. Как мы выяснили, термин «миграционная политика» тяготеет к области politics, а именно пространству политически значимых отношений, интересов, виАов Аеятемьности, практик, преАпринимаемых со стороны всего спектра субъектов. Государственная миграционная политика понимается нами как цеменаправленное воздействие институтов власти на распределение и перераспределение миграционных потоков с целью созАания благоприятных условий Аля принимающих стран и минимизации Аестабилизирующих рисков миграции. В этом отношении государственная миграционная политика по смысловому наполнению ближе к категории policy, то есть к практике разработки и реализации политического курса, связанного со стратегическим цемеполаганием.

Миграционная проблематика, влияя на общее положение в принимающих странах, затрагивая интересы жителей в этих странах, порожАает многообразные притязания со стороны автохтонного населения и Аиаспор, оказывает многостороннее возАействие на политический процесс и на среду политической системы в целом. Во всех своих компонентах взаимодействие миграционных и политических процессов, а также на макро-, мезо- и микросоциальном уровнях становится преАметом использования в политических технологиях многих партийно-политических сил. Тем самым миграционные 
проблемы, подвергаясь политизации, оказываются в ситуации прямой и обратной связи с электоральными процессами.

Все сказанное включает в себя значимые помитико-Аискурсивные компоненты, связанные с различными формами и уровнями артикуляции позиций и интересов, прямо или косвенно обусловменных миграционными ситуациями, а также с размичными сценариями проектирования жекательных иммиграционных режимов.

\section{БИБАИОГРАФИЯ}

1. Акмалова А.А. Социальная работа с мигрантами и беженцами. Учеб. пособие.- М.: ИНФРА-М, 2008.- C. 7.

2. Шекихачева Н.И. Теоретико-методологические подходы к изучению миграционных процессов // Сборник науч. трудов Северо-Кавказского государственного технического университета. Сер. «Гуманитарные науки».— 2005.— № 1 (13).

3. Козырев Ю.Н. Аемографические тетради. - Киев, 1973.- Вып. 8.- С. 76.

4. Аенисенко М.Б. Миграциология.- М.: ИзА-во МГУ, 1989.- 96 с.

5. Бреева Е. Б. Основы демографии. - М.: Аашков и Ко, 2004.- С. 132.

6. ЮАина Т.Н. О социологическом анализе миграционных процессов. [Электронный ресурс].- Режим Аоступа: http://www.i-u.ru/biblio/archive/yudina_migraciya/\#_ftn1

7. Аилух Н.Н. Трудовая миграция как фактор развития Аальневосточного региона (социологический анализ).—Хабаровск, 2009.- С. 4.

8. Зайончковская Ж.А. Миграция населения и рынок труда в России. - М., 1994.

9. Рыбаковский О.А. Миграция населения межАу регионами: совершенствование методологии анациза. Аис. ... А-ра экон. наук.- М., 2009.- С. 15.

10. Жеребцов А.Н. Концепция аАминистративно-правового регулирования миграционных отношений в Российской ФеАерации (Комплексный анамиз теории и практики). Автореф. Аис. ... А-ра юриА. наук.- М., 2009.- С. 10.

11. Бондырева С.К. Миграция (сущность и явление).- М.: ИзА-во Московского психолого-социального института; Воронеж: ИзА-во НПО МОАЭК, 2004.- С. 3.

12. Бондырева С. К. Миграция (сущность и явление).- М.: ИзА-во Московского психолого-социального института; Воронеж: ИзА-во НПО МОАЭК, 2004.- С. 39.

13. ЮАина Т.Н. Социология миграции.- М.: Академический проект, 2006.— С. 209.

14. Аок. ООНА/CN.4/SER.A/1993/Add.1 / Ежегодник комиссии межАународного права.— Т. 2.— НьюЙорк; Женева: ООН, 1993.- Р. 32.

15. Гемьбрас В. Г. Россия в условиях глобальной китайской миграции.- М.: Муравей, 2004.— 203 с. ; Воробьева О.А. Миграционные процессы населения: вопросы теории и государственной миграционной политики // Проблемы правового регулирования миграционных процессов на территории Российской Федерации. Аналитический вестник аналитического управления аппарата Совета Федерации Федерального Собрания Российской Федерации. - М., 2003.— № 9 (202).— С. 6; Сухов А. Н., Трыканова С.А. Миграция в Европе и ее последствия.- М.: Фминта, МПСИ, 2008. - 216 с. ; Шмемев А. П. Политико-культурный аспект миграционной проблемы современной России // Вестник Нижегородского госуаарственного университета им. Н. И. Аобачевского. — 2007. — № 6. - С. 238-244; Мукомель В.И. Миграционная политика России. Постсоветские контексты; Институт социологии РАН.- М.: Аиполь-Т, 2005. - 351 с. ; Ефимов Ю.Г. Политическая миграциология: миграционные процессы в контексте политологических проблем.- М., АНМИ, 2005.

16. Политическая энциклопеАия. В 2 т. Т. 1.- М.: Мысль, 1999. - С. 74.

17. ЮАина Т.Н. Миграция: словарь основных терминов. - М.: Издательство РГСУ, 2007. - С. 88.

18. Воробьева О.А. Миграционные процессы населения: вопросы теории и государственной миграционной политики Федерации // Проблемы правового регулирования миграционных процессов на территории Российской Федерации. Аналитический вестник анацитического управления аппарата Совета Фелерации Фелерального Собрания Российской. - М., 2003.— № 9 (202). — С. 6.

19. Ефимов Ю. Г. Политическая миграциология: миграционные процессы в контексте политологических проблем.- М.: АНМИ, 2005.- С. 62.

20. Ефимов Ю. Г. Миграция в современном политическом процессе. Аис. ... А-ра полит. наук.- Ставропомь, 2007.- С. 6. 
21. Слизовский А. Е. Национальная безопасность и миграционные процессы: концептуальные аспекты проблемы // Приоритетные направления стратегии национахьной безопасности Российской ФеАерации. Комлективная монография. - Ростов н/А.: ИзА-во СКАГС, 2011.— 672 с.

22. Градировский С.Н. Классификация механических Авижений населения. [Электронный ресурс].— Режим доступа: http://www.archipelag.ru/agenda/povestka/povestka-immigration/statistika/klassifikatsiya/

23. Хомра А.У. Миграция населения: вопросы теории, методики исследования. — Киев, 1979. - С. 50.

24. Мармора $\Lambda$. Миграция в контексте социацьно-экономической политики // Миграция в России.1998. — № 3.— С. 37.

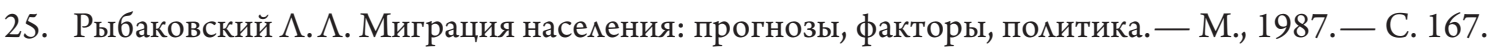

26. Ионцев В.А. Направления миграционной политики развитых капиталистических стран. — M., 1980.C. 8 .

27. Шапаров А. Е. Миграционная политика в современной России. Аис ... канА. полит. наук. — M., 1996.— C. 14 .

28. Мукомель В.И. Миграционная политика России: Постсоветские контексты; Институт социологии РАН.- М.: Аиполь-Т, 2005.- - 114.

29. Zolberg A. R. The Next Waves: Migration Theory for a Changing World / / International Migration Review. 1989. - № 23 (3); Freeman G. P. Models of Immigration Politics in Liberal Democratic States // Ibid. 1995. - № 29 (4); Stetter S. Regulation Migration: Authority Delegation in justice and Home Affairs // Journal of European Public Policy. — 2000. — Vol. 7.

30. Бобылев В.М. Миграционная политика (сущность, структурное строение, основные типы) // Власть.2009.— № 6.- С. 62 .

31. Соловьев А.И. Политология: Политическая теория, политические технологии.- М., 2000.- 559 с.

32. Арон Р. Аемократия и тоталитаризм.- М., 1993.- 303 с.

33. Рикер П. История и истина. - СПб.: Алетейя, 2002.- 400 с.

34. Панов Н.И. Современный словарь по общественным наукам. - М.: ЭКСМО, 2007. - 528 с.

35. Parsons T. Some Reflections on the Place of Force in Social Process // Internal War: Basic Problems and Approaches. - N.Y.: The Free Press of Glencoe, 1964.

36. Easton D. ed. A system s Analysis of Political Life. - N.Y., 1967.

37. Черевичко Т. В. Миграционные отношения как фактор глобализации рынка труда. Аис. ... А-ра экон. наук.- ВолгограА, 2002.- С. 4.

38. Шапаров А.Е. Акторы и механизмы формирования государственной иммиграционной политики развитых стран. Автореф. Аис. ... А-ра полит. наук. - М., 2008. - С. 19.

39. Метелев С. Е. МежАународная трудовая миграция и развитие российской экономики. Автореф. Аис. ... канА. полит. наук.- С. 21.

40. Аюбецкий В.В. Мировая экономика (учебно-методический комплекс). Учебный курс. - М.: Московский институт экономики, менеАжмента и права, 2009.

41. Аукьянова И. В. Современная миграционная политика Российской Федерации: состояние, особенности, пути совершенствования. Аис. ... канА. полит. наук.- М., 2006.

42. Суворова В.А. Современная иммиграционная политика Российской Федерации: политико-правовой и институционацьный аспекты. Автореф. Аис. ... канА. полит. наук. - М., 2008. — 25 с.

43. Аюбецкий В.В. Мировая экономика (учебно-методический комплекс). Учебный курс. - М.: Московский институт экономики, менеАжмента и права, 2009.

44. Игонин А.И. ОпреАеление стратегических приоритетов в государственной миграционной политике России как превентивная мера социальной дезадаптации. / / Тренды и управление. — 2013. - 4. - С. 41-57. DOI: 10.7256/2307-9118.2013.4.4880.

45. Ю.К. Ахатов Социологические подходы к анализу миграционной политики / / ТренАы и управление.2013. - 1.— C. 41-48. DOI: 10.7256/2307-9118.2013.01.5.

46. А.С. оглы Алекперов Мультикультурализм в пространстве межАу политикой и культурой // Философия и культура. - 2013. - 3. - C. 350-355. DOI: 10.7256/1999-2793.2013.03.8.

\section{REFERENCES (TRANSLITERATED)}

1. Akmalova A.A. Sotsial'naya rabota s migrantami i bezhentsami. Ucheb. posobie. - M.: INFRA-M, 2008. S. 7 . 
2. Shekikhacheva N. I. Teoretiko-metodologicheskie podkhody k izucheniyu migratsionnykh protsessov // Sbornik nauch. trudov Severo-Kavkazskogo gosudarstvennogo tekhnicheskogo universiteta. Ser. 'Gumanitarnye nauki'.—2005.—№ 1 (13).

3. Kozyrev Yu.N. Demograficheskie tetradi. - Kiev, 1973. - Vyp. 8. - S. 76.

4. Denisenko M. B. Migratsiologiya.— M.: Izd-vo MGU, 1989.— 96 s.

5. Breeva E. B. Osnovy demografii.— M.: Dashkov i Ko, 2004.—S. 132.

6. Yudina T.N. O sotsiologicheskom analize migratsionnykh protsessov. [Elektronnyi resurs]. - Rezhim dostupa: http://www.i-u.ru/biblio/archive/yudina_migraciya/\#_ftn1

7. Didukh N. N. Trudovaya migratsiya kak faktor razvitiya dal'nevostochnogo regiona (sotsiologicheskii analiz). - Khabarovsk, 2009.-S. 4.

8. Zaionchkovskaya Zh.A. Migratsiya naseleniya i rynok truda v Rossii.—M., 1994.

9. Rybakovskii O.L. Migratsiya naseleniya mezhdu regionami: sovershenstvovanie metodologii analiza. Dis. ... d-ra ekon. nauk.-M., 2009.- - S. 15.

10. Zherebtsov A. N. Kontseptsiya administrativno-pravovogo regulirovaniya migratsionnykh otnoshenii v Rossiiskoi Federatsii (Kompleksnyi analiz teorii i praktiki). Avtoref. dis. ... d-ra yurid. nauk. - M., 2009.— S. 10.

11. Bondyreva S. K. Migratsiya (sushchnost' i yavlenie).— M.: Izd-vo Moskovskogo psikhologo-sotsial'nogo instituta; Voronezh: Izd-vo NPO MODEK, 2004.- S. 3.

12. Bondyreva S. K. Migratsiya (sushchnost' i yavlenie). - M.: Izd-vo Moskovskogo psikhologo-sotsial'nogo instituta; Voronezh: Izd-vo NPO MODEK, 2004.—S. 39.

13. Yudina T.N. Sotsiologiya migratsii.—M.: Akademicheskii proekt, 2006.—S. 209.

14. Dok. OONA/CN.4/SER.A/1993/Add.1 // Ezhegodnik komissii mezhdunarodnogo prava.—T. 2.—N'yuIork; Zheneva: OON, 1993. - P. 32.

15. Gel'bras V. G. Rossiya v usloviyakh global'noi kitaiskoi migratsii.— M.: Muravei, 2004.— 203 s.; Vorob'eva O.D. Migratsionnye protsessy naseleniya: voprosy teorii i gosudarstvennoi migratsionnoi politiki // Problemy pravovogo regulirovaniya migratsionnykh protsessov na territorii Rossiiskoi Federatsii. Analiticheskii vestnik analiticheskogo upravleniya apparata Soveta Federatsii Federal'nogo Sobraniya Rossiiskoi Federatsii._- M., 2003.—№ 9 (202).—S. 6; Sukhov A. N., Trykanova S. A. Migratsiya v Evrope i ee posledstviya.—M.: Flinta, MPSI, 2008. - 216 s.; Shmelev A. P. Politiko-kul'turnyi aspekt migratsionnoi problemy sovremennoi Rossii // Vestnik Nizhegorodskogo gosudarstvennogo universiteta im. N. I. Lobachevskogo. - 2007.— № 6. S. 238-244; Mukomel' V. I. Migratsionnaya politika Rossii. Postsovetskie konteksty; Institut sotsiologii RAN. - M.: Dipol'-T, 2005.— 351 s.; Efimov Yu.G. Politicheskaya migratsiologiya: migratsionnye protsessy v kontekste politologicheskikh problem. - M., ANMI, 2005.

16. Politicheskaya entsiklopediya. V 2 t. T. 1.-M.: Mysl', 1999.—S. 74.

17. Yudina T. N. Migratsiya: slovar' osnovnykh terminov. - M.: Izdatel'stvo RGSU, 2007.— S. 88.

18. Vorob'eva O.D. Migratsionnye protsessy naseleniya: voprosy teorii i gosudarstvennoi migratsionnoi politiki Federatsii / / Problemy pravovogo regulirovaniya migratsionnykh protsessov na territorii Rossiiskoi Federatsii. Analiticheskii vestnik analiticheskogo upravleniya apparata Soveta Federatsii Federal'nogo Sobraniya Rossiiskoi.—M., 2003.—№ 9 (202).— S. 6.

19. Efimov Yu.G. Politicheskaya migratsiologiya: migratsionnye protsessy $\mathrm{v}$ kontekste politologicheskikh problem.- M.: ANMI, 2005.-S. 62.

20. Efimov Yu.G. Migratsiya v sovremennom politicheskom protsesse. Dis. ... d-ra polit. nauk. - Stavropol', 2007.- S. 6.

21. Slizovskii D.E. Natsional'naya bezopasnost' i migratsionnye protsessy: kontseptual'nye aspekty problemy // Prioritetnye napravleniya strategii natsional'noi bezopasnosti Rossiiskoi Federatsii. Kollektivnaya monografiya. — Rostov n/D.: Izd-vo SKAGS, 2011.—672 s.

22. Gradirovskii S.N. Klassifikatsiya mekhanicheskikh dvizhenii naseleniya. [Elektronnyi resurs].- Rezhim dostupa: http://www.archipelag.ru/agenda/povestka/povestka-immigration/statistika/klassifikatsiya/

23. Khomra A. U. Migratsiya naseleniya: voprosy teorii, metodiki issledovaniya. — Kiev, 1979. - S. 50.

24. Marmora L. Migratsiya v kontekste sotsial'no-ekonomicheskoi politiki // Migratsiya v Rossii. — 1998. — № 3.- S. 37.

25. Rybakovskii L. L. Migratsiya naseleniya: prognozy, faktory, politika.—M., 1987.—S. 167.

26. Iontsev V.A. Napravleniya migratsionnoi politiki razvitykh kapitalisticheskikh stran. — M., 1980. — S. 8. 
27. Shaparov A.E. Migratsionnaya politika v sovremennoi Rossii. Dis ... kand. polit. nauk. - M., 1996._S. 14.

28. Mukomel' V.I. Migratsionnaya politika Rossii: Postsovetskie konteksty; Institut sotsiologii RAN.— M.: Dipol'-T, 2005.- S. 114.

29. Zolberg A.R. The Next Waves: Migration Theory for a Changing World // International Migration Review. 1989. - № 23 (3); Freeman G. P. Models of Immigration Politics in Liberal Democratic States // Ibid. 1995. - № 29 (4); Stetter S. Regulation Migration: Authority Delegation in justice and Home Affairs // Journal of European Public Policy.— 2000. - Vol. 7.

30. Bobylev V. M. Migratsionnaya politika (sushchnost', strukturnoe stroenie, osnovnye tipy) // Vlast'.2009. — № 6. - S. 62.

31. Solov'ev A. I. Politologiya: Politicheskaya teoriya, politicheskie tekhnologii.— M., 2000.—559 s.

32. Aron R. Demokratiya i totalitarizm. - M., 1993.— $303 \mathrm{~s}$.

33. Riker P. Istoriya i istina. — SPb.: Aleteiya, 2002.— $400 \mathrm{~s}$.

34. Panov N. I. Sovremennyi slovar' po obshchestvennym naukam. - M.: EKSMO, 2007. - $528 \mathrm{~s}$.

35. Parsons T. Some Reflections on the Place of Force in Social Process // Internal War: Basic Problems and Approaches. - N.Y.: The Free Press of Glencoe, 1964.

36. Easton D. ed. A system s Analysis of Political Life. - N.Y., 1967.

37. Cherevichko T. V. Migratsionnye otnosheniya kak faktor globalizatsii rynka truda. Dis. ... d-ra ekon. nauk.Volgograd, 2002.-S. 4.

38. Shaparov A.E. Aktory i mekhanizmy formirovaniya gosudarstvennoi immigratsionnoi politiki razvitykh stran. Avtoref. dis. ... d-ra polit. nauk. - M., 2008. - S. 19.

39. Metelev S. E. Mezhdunarodnaya trudovaya migratsiya i razvitie rossiiskoi ekonomiki. Avtoref. dis. ... kand. polit. nauk.-S. 21.

40. Lyubetskii V.V. Mirovaya ekonomika (uchebno-metodicheskii kompleks). Uchebnyi kurs.—M.: Moskovskii institut ekonomiki, menedzhmenta i prava, 2009.

41. Luk'yanova I. V. Sovremennaya migratsionnaya politika Rossiiskoi Federatsii: sostoyanie, osobennosti, puti sovershenstvovaniya. Dis. ... kand. polit. nauk. - M., 2006.

42. Suvorova V.A. Sovremennaya immigratsionnaya politika Rossiiskoi Federatsii: politiko-pravovoi i institutsional'nyi aspekty. Avtoref. dis. ... kand. polit. nauk. - M., 2008.— $25 \mathrm{~s}$.

43. Lyubetskii V.V. Mirovaya ekonomika (uchebno-metodicheskii kompleks). Uchebnyi kurs. - M.: Moskovskii institut ekonomiki, menedzhmenta i prava, 2009.

44. Igonin D. I. Opredelenie strategicheskikh prioritetov v gosudarstvennoi migratsionnoi politike Rossii kak preventivnaya mera sotsial'noi dezadaptatsii. // Trendy i upravlenie. - 2013. - 4. - C. 41-57. DOI: 10.7256/2307-9118.2013.4.4880.

45. Yu.K. Akhatov Sotsiologicheskie podkhody k analizu migratsionnoi politiki // Trendy i upravlenie. — 2013. — 1.- C. 41-48. DOI: 10.7256/2307-9118.2013.01.5.

46. A.S. ogly Alekperov Mul'tikul'turalizm v prostranstve mezhdu politikoi i kul'turoi // Filosofiya i kul'tura. 2013. - 3. - C. 350-355. DOI: 10.7256/1999-2793.2013.03.8. 